\title{
The Influence of SME's Collaboration on SME Innovation Capabilities
}

\author{
Susanta1 , Humam Santoso Utomo ${ }^{2}$, Lita Yulita Fitriyani ${ }^{3}$, Keny Rahmawati ${ }^{4}$ \\ 1,2,4 Business Administration, Universitas Pembangunan Nasional "Veteran" Yogyakarta, Indonesia; \\ ${ }^{3}$ Accounting Department, Universitas Pembangunan Nasional “Veteran” Yogyakarta, Indonesia
}

\begin{abstract}
The ability to innovate is indispensable in a turbulent external environment. SME's in Bantul Yogyakarta formed a group of non-formal organizations to overcome business difficulties during the pandemic by increasing business innovation capabilities. This study also aims to examine the effect of SME's collaboration on innovation capability during the COVID-19 pandemic This research is important to do obtain information on the effectiveness of SME collaboration to create innovation and achieve SME performance. During a pandemic where the business environment is increasingly dynamic, this research is increasingly needed to obtain an effective collaboration model. The research was conducted on 100 local processed food SME's using a quantitative approach. The research instrument was in the form of a questionnaire equipped with interviews to obtain comprehensive data and information. The analytical tool used is WarpPLS. The results show that SME's collaboration has a significant effect on innovation capabilities.
\end{abstract}

Keywords: SME's, SME's Collaboration, Innovation Capabilities.

\section{INTRODUCTION}

This is an open access article under the CC-BY-NC license

Today, the Covid-19 pandemic has also had a tremendous impact on the economy in Indonesia, thus affecting the performance of SMEs. SMEs' access to the market is hampered because the situation requires business centers to reduce their business activities or even close their activities. The uncertain business environment (environmental uncertainty) is perceived as an obstacle for SMEs to improve performance. Environmental dynamism has been felt by SMEs so that it affects the business they do.

One of the SMEs affected by the COVID-19 disaster is a SMEs engaged in the food processing sector, namely the processed food group, which is located in the Bantul area, Yogyakarta. On February 2, 2021, observations and interviews were held with processed food business actors in Bantul through the Focus Group Discussion method, according to them, the COVID-19 pandemic has greatly impacted the sustainability of their business, although not all SMEs feel the negative impact of this disaster. The impact experienced by each SME is different, such as a decrease in sales; an increase in the price of raw goods which results in an inefficient production process, stagnant product distribution, and other negative impacts. This impact causes the performance of SMEs to decline in the 2020 period, both in terms of markets and financially. There are several factors that affect the performance of SMEs, namely internal factors and external factors. The ability to innovate and collaborate among SMEs (SME Collaboration) is an internal factor that affects the performance of SMEs.

UPN "Veteran" Yogyakarta together with the Regional Government of Bantul Regency, in 2010 formed a group of locally processed food SMEs and is still developing. SME groups collaborate in overcoming business problems that cannot be overcome alone. So far, there is still very limited research that reveals the collaborative role of SMEs in times of crisis. Therefore, this research is directed to determine the effectiveness of SME Collaboration in improving innovation capabilities during a pandemic. The results of this study are expected to provide important information on the role of SME groups in overcoming the problems of each group member.

Based on the description above, there is sufficient reason that this research is urgent to be carried out. Here are some reasons why this research is important:

1. The existence of SMEs in times of crisis is very necessary as a supplier of jobs so that the performance of SMEs needs to be maintained. 
The Influence of SME's Collaboration on SME Innovation Capabilities

Susanta, Humam Santoso Utomo, Lita Yulita Fitriyani, Keny Rahmawati

2. Testing the effectiveness of SME Collaboration and Absorptive Capacity on SMEs' innovation capability is still very limited. The SME groups have not received enough attention from researchers as to whether their collaboration is effective in times of crisis.

\section{LITERATURE REVIEW}

\section{Resource Based View Theory}

Resource-Based View (RBV) was used as a reference to determine the relationship between the concepts in this researh. RBV analyzes and interprets organizational resources to understand how organizations achieve sustainable competitive advantage so as to achieve defined performance. Hard to imitate concept of attributes by competitors is caused by uniqueness within the organization because resources are not easily transferred, as well as major changes in the organizational culture. According to Conner (1991), ownership of inputs and unique capabilities possessed by a company's resources are factors that affect the variance of performance between companies. The internal factor that has an impact on the company's advantage is the ability of SMEs to absorb information related to the business they are running so as to create unique products in the form of innovation. In addition, there are also external factors that have an impact on the company's advantages, which have implications for performance. The external environment in the form of collaboration between SMEs in the group and the dynamics of the environment that are expected to hinder or encourage the performance of SMEs are the context in this research.

\section{SME's Collaboration}

SME Collaboration shows the cooperation of SMEs with external parties. The parties that can be involved with SMEs include fellow SMEs, groups of SMEs that have a structure, larger companies, the government, and universities. New product development can be created if there is an expansion in the various skills of SMEs due to collaboration between companies and external institutions. According to Muscio (2014) and Forfas (2005), companies must have the ability to search, find, access, and interpret their own user information embodied in external organizations. SMEs that can utilize external networks efficiently are a determining factor for the success of SMEs against competitors.

\section{Innovation Capability}

According to Battor \& Battor (2010); Sivadas \& Dwyer (2000) innovation is an important organizational capability, because with the success of a new product, it will have an impact on increasing sales, profits and competi, and strength. Hult et al. (2004) the process, product, and organization of a new idea are described as innovation (Thornhill, 2006). Therefore, Innovation Capability in the context of this research is the ability of SMEs to develop new products according to market demand.

\section{The Effect of Collaboration on Innovation}

Expansion of expertise in accessing new knowledge will occur if there is collaboration between companies and external institutions. The existence of collaboration between companies and institutions, causes companies to have the ability to search, find, access, and interpret information (Forfás, 2005).

Collaboration among SMEs has a positive effect on increasing information, experience, and knowledge so that each SME has ideas or ideas to develop product and service innovations. The company's collaboration with external institutions allows for the expansion of expertise and can support the development of new products. Piore and Sabel (1984) reveal that the competitiveness of a company's innovation is more determined by the company's external network (Mytelka, 1991). The results of Costa \& Monteiro's research (2016) found a link between knowledge sharing, absorptive capacity, and innovation.

Strategic alliances among SMEs can overcome various obstacles to growth. Therefore, the collaboration of SMEs has a positive impact on the performance of SMEs. Based on this argument, the following hypothesis is formulated: SME's collaboration has a significant effect on innovation. 


\section{RESEARCH METHODOLOGY}

This type of research is applied which is intended to evaluate the application of business collaboration between SMEs. In addition, a collaboration between SMEs and other parties such as local governments, universities, and industry. This study also examines and explains the causal relationship between variables through hypothesis testing as well as conducting explanations. The approach used in analyzing this research is quantitative (Kerlinger, 2003). The population in this study were all SMEs of local processed food who were members of the AMBOY Group (Agro Mirasa Boga Yogyakarta) in Bantul Yogyakarta, totaling 62 SMEs. Given the relatively small number, all members of the population were used as respondents for this study.

The SME's Collaboration variable was measured using an instrument developed by Zahra and George (2002), while the Innovation Capability indicator adopted Thornhill's (2006) research. The measurement scale used in this study is an attitude scale. The type of scale used is a Likert scale which is graded between a score of 1-5 (1=strongly disagree to $5=$ strongly agree). The main data used in this study is primary data derived from the respondents' answers, namely the owners of locally processed food SMEs. This study uses a closed questionnaire as a research instrument that is given directly to respondents through faceto-face or social media. Before being used, the questionnaire was tested for validity and reliability using the Product Moment correlation and the Cronbach Alpha coefficient. The analysis of this study used descriptive statistical analysis and inferential statistical analysis. The inferential statistical tool used is WarpPLS (Warp-Partial Least Square) with considerations relevant to the research objectives and WarpPLS is suitable for research with large or small sample sizes (Hair et al., 2014). Hypothesis testing using p-value with a significance level of 5\%.

\section{FINDING AND DISCUSSION}

Based on the data collection of research respondents, the following results can be presented:

Table 1. Respondent Characteristics

\begin{tabular}{lll}
\hline \multicolumn{2}{c}{ Respondent Characteristics } & \multicolumn{1}{c}{ Value $(\mathbf{n = 1 0 0})$} \\
\hline \multirow{2}{*}{ Gender } & Male & 84 \\
\cline { 2 - 3 } & Female & 16 \\
\hline \multirow{2}{*}{ Respondent Age } & $<25$ years & 15 \\
\cline { 2 - 3 } & 25-40 years & 60 \\
\cline { 2 - 3 } Company Age & $1-5$ years & 25 \\
\cline { 2 - 3 } & 5-10 years & 7 \\
\cline { 2 - 3 } & $10-15$ years & 26 \\
\cline { 2 - 3 } & $15-20$ years & 23 \\
\cline { 2 - 3 } & $>20$ years & 8 \\
\hline
\end{tabular}

Table 2. Average of Variables and Indicators

\begin{tabular}{clc}
\hline Variabel & \multicolumn{1}{c}{ Indikator } & Mean \\
\hline SME's & - Coolaboration with SME & 4,33 \\
Collaboration & - Collaborative with high education & 4.21 \\
& - Collaborative with local government & 4,02 \\
& - Collaborative with industry & 4,05 \\
\hline Innovation & - Ability to create new product innovations & 4,24 \\
Capability (Y1) & - Ability to create new service & 4,46 \\
\hline
\end{tabular}


The results of model testing using WarpPLS are as follows:

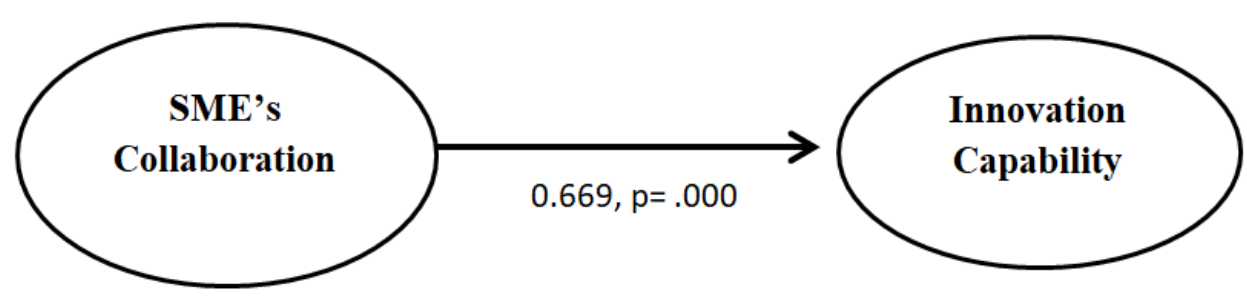

Figure 1. Tested Model

The results of this study indicate that SME Collaboration has a significant effect on Innovation Capability. This result is evidenced by the p-value $<0.05$ with a coefficient of 0.669 . Thus, the hypothesis is accepted. The findings of this study are consistent with Piore and Sabel (1984) who revealed that the innovation competitiveness of a company is more determined by the company's external network. This finding also supports previous research conducted by Costa \& Monteiro (2016) which found a link between knowledge sharing, absorptive capacity, and innovation.

These findings provide theoretical implications and managerial implications. This finding further strengthens the RBV (Barney, 1991; Hamel and Prahalad, 1996) that organizational resources are useful in creating a sustainable competitive advantage through innovation. Collaboration among SMEs expands their ability to understand the changing environment and create new products or new services according to consumer needs. The results of this study reveal that longstanding cooperation among SMEs has fostered a strong commitment to helping each other. The SME group discusses finding solutions to problems that occur due to the covid-19 pandemic. They find fresh ideas to maintain their business during the pandemic.

The findings of this study are useful for SMEs and stakeholders in maintaining SMEs in times of crisis. The government needs to formulate regulations in providing business assistance to SMEs through SME groups. Assistance is directed at increasing the ability of SMEs in product innovation and marketing innovation that is relevant to the pandemic situation.

\section{CONCLUSION AND FURTHER RESEARCH}

An important finding of this research is that SME collaboration has a significant effect on innovation. Cooperation between SMEs during the COVID-19 pandemic has proven to increase the innovation ability of SMEs in creating new products and new marketing techniques. This study has limitations in terms of the scope of the study. Further research is expected to be able to research with a larger population from various business sectors.

\section{REFERENCES}

Adler, P. S., \& Shenbar, A. (1990). Adapting your technological base: The organizational challenge. Sloan Management Review, 25, 25e37.

Barney, J. B. (1991). Firm resources and sustained competitive advantage. Journal of Management, $17(1), 99 \mathrm{e} 120$

Battor, M., \& Battor, M. (2010). The impact of customer relationship management capability on innovation and performance. Journal of Marketing Management, 26(9e10), 842e857.

Conner, K. (1991), -Historical comparison of resource-based theory and five schools of thought within industrial organization economics: Do we have a new theory of the firm? Journal of Management, 17(1), pp.121-154

Costa, V. and Monteiro, S. (2016). Knowledge Processes, Absorptive Capacity and Innovation: A Mediation Analysis Knowledge and Process Management Volume 23 Number 3 pp 207-218 (2016) Published online 20 May 2016 in Wiley Online Library (www.wileyonlinelibrary.com) DOI: $10.1002 / \mathrm{kpm} .1507$

Forfás, (2005) Making Technological Knowledge Work: A Study of the Absorptive Capacity of Irish SMEs, Dublin. 
Hamel, G. and Prahalad, C. (1996), Competing for the Future, Harvard Business School Press, Paperback edition, Boston (Massachusetts).

Hult, G. T., Hurley, R., \& Knight, G. (2004). Innovativeness: Its antecedents and impact on business performance. Industrial Marketing Management, 33(5),429e438.

Mikhailov, A., \& Reichert, F. M. (2019). Influence of absorptive capacity on innovation: A systematic literature review. Revista de Administração Mackenzie, 20(6). doi:10.1590/ 16786971/eRAMD190033

Moilanen, M., Østbye, S., and Woll, K. (2014). Non-R\&D SMEs: external knowledge, absorptive capacity and product innovation Small Bus Econ. DOI 10.1007/s11187-014-9545-9

Muscio, A. (2014). The Impact of Absorptive Capacity on SMEs' Collaboration. Economics of Innovation and New Technology • November 2007 DOI: 10.1080/10438590600983994 • Source: RePEc

Mytelka, L., (1991) Crisis, technological change and the strategic alliance, in: Mytelka, L. (ed.), Strategic Partnerships and the World Economy. Pinter, London.

Rothwell, R. and Dodgson, M. (1991) External Linkages and Innovation in Small and Medium-sized Enterprises, R\&D Management 21, 125-137.

Schmitz, H., (1999) Collective Efficiency and Increasing Returns. Cambridge Journal of Economics 23(4).

Thornhill, S. (2006). Knowledge, Innovation and firm performance in high and low technology regimes. Journal of Busienss Venturing, 21(5), 687-703.

Utomo, H.S. and Susanta (2020). The Effect of Digital Marketing Capability Against Marketing Performance with Innovation as mediation (Study on Batik SMEs during the Covid-19 Pandemic. LPPM UPN “Veteran” Yogyakarta Conference Series Proceeding on Political and Social Science (PSS) Volume 1 Number 1 (2020): 166-173

Van Dijk, B., den Hertog, R., Menkveld, B., Thurk, R., (1997) Some new evidence on the determinants of large- and small-firm innovation. Small Business Economics 9, pp.335-343.

Zahra, S. A., \& George, G. (2002). Absorptive capacity: A review, reconceptualization, and extension. Academy of Management Review, 27(2), 185-203. doi:10.5465/AMR.2002.6587995

Zawislak, P. A., Cherubini Alves, A., Tello-Gamarra, J., Barbieux, D., \& Reichert, F. M. (2012). Innovation capability: From technology development to transaction capability. Journal of Technology Management \& Innovation, 7(2), 14-27. doi:10.4067/s0718-27242012000200002

Zhai, Y-M., Sun, W-Q., Tsai, S-B., Wang, Z., Zhao, Y., and Chen, Q. (2018). An Empirical Study on Entrepreneurial Orientation, Absorptive Capacity, and SMEs' Innovation Performance: A Sustainable Perspective. Sustainability 2018, 10, 314; doi:10.3390/su10020314 